\title{
EFEK MODEL PEMBELAJARAN INQUIRY TRAINING BERBASIS MEDIA KOMPUTER TERHADAP KETERAMPILAN PROSES SAINS DAN KEMAMPUAN BERPIKIR KRITIS SISWA
}

\author{
Andar M. Hutagalung \\ Jurusan Pendidikan Fisika-Pascasarjana Universitas Negeri Medan
}

\begin{abstract}
Abstrak. Tujuan penelitian ini adalah untuk mengetahui apakah ada perbedaan keterampilan proses sains dan kemampuan berpikir kritis siswa dengan menerapankan model pembelajaran Inquiry Training berbasis media komputer, dengan penerapan model pembelajaran Inquiry Training. Metode yang digunakan dalam penelitian ini adalah quasi eksperimen atau perlakuan terhadap dua variabel (kelas), satu kelas sebagai kelas eksperimen yang diberikan perlakuan dengan penerapan model pembelajaran Inquiry Training berbasis media komputer dan kelas yang lain sebagai kelas kontrol melalui penerapan model pembelajaran Inquiry Training. Data hasil penelitian mendapatkan $\mathrm{N}$-gain keterampilan proses sains kelas eksperimen sebesar 0,84 (kategori tinggi) dan $\mathrm{N}$-gain kelas kontrol sebesar 0,68 (kategori sedang). Sedangkan pada keterampilan berpikir kritis siswa $\mathrm{N}$-gain kelas eksperimen sebesar 0,75 (kategori tinggi) dan $\mathrm{N}$-gain kelas kontrol sebesar 0,67 (kategori sedang). Dari hasil tersebut dapat disimpulkan model pembelajaran Inquiry training berbasis media komputer yang diterapkan pada kelas eksperimen secara signifikan dapat lebih meningkatkan keterampilan proses sains dan kemampuan berpikir kritis siswa dibandingkan dengan model pembelajaran inquiry training yang diterapkan pada kelas kontrol.
\end{abstract}

Kata kunci: model pembelajaran, inquiry training, media komputer, keterampilan proses sains, berpikir kritis

\section{EFEK MODEL PEMBELAJARAN INQUIRY TRAINING BERBASIS MEDIA KOMPUTER TERHADAP KETERAMPILAN PROSES SAINS DAN KEMAMPUAN BERPIKIR KRITIS SISWA}

\section{Andar M. Hutagalung \\ Department of Physical Education-Graduate State University of Medan}

\begin{abstract}
The purpose of the research is to know if there is any difference between the skill of students in a science process and the students critically thinking ability using inquiry training's model of computer base. The method used in the research is quasi experiment or consisting two variables (classes), one class used as an experiment and one as a control class. The result shown that skill of students in a science process are $\mathrm{N}$-gain experiment class 0.84 (high category) and control class 0.68 (medium category). On the contrary based on the students critically thinking ability of $\mathrm{N}$-gain experiment class 0.75 (high category) and control class 0.67 (medium category). Therefore
\end{abstract}


inquiry training's model of computer base significantly give a better outcome than inquiry training's model.

Keywords: learning model, inquiry training, computer media, the skill of science process, the critically thinking ability

\section{PENDAHULUAN}

Keterampilan proses sains sangat penting dimiliki siswa karena sebagai persiapan dan latihan dalam menghadapi kenyataan hidup di dalam masyarakat sebab siswa dilatih untuk berpikir logis dalam memecahkan masalah. Gage (Wartono, 2003) mengungkapkan bahwa dalam mengembangkan keterampilan proses sains anak harus dibuat kreatif, ia akan mampu mempelajari IPA ditingkat yang lebih tinggi dalam waktu yang singkat.

Kemampuan berpikir kritis merupakan kemampuan yang akan digunakan untuk mengintegrasikan konsep yang diterima dari proses pembelajaran di sekolah dengan masalah yang akan dihadapi pada kehidupan sehari-hari. Oleh karena itu, sekolah sebaiknya tidak hanya menekankan pada pemahaman konsep siswa tetapi juga keterampilan berpikirnya.

Berdasarkan hasil pengamatan dan pengalaman di lapangan yang dilakukan di SMP Negeri 3 Balige, model pembelajaran yang digunakan oleh guru Fisika selama ini cenderung menggunakan model konvensional dengan urutan ceramah, tanya jawab dan penugasan. Dalam proses pembelajaran guru tidak menyesuaikan dengan karakteristik materi pembelajaran. Dengan metode ini siswa hanya memperoleh sejumlah informasi yang bersumber dari guru saja. Informasi dan komunikasi yang terjadi satu arah ini menyebabkan siswa lebih banyak menunggu tanpa berbuat sesuatu untuk menemukan sendiri konsep-konsep Fisika. Guru lebih banyak berbuat, sementara siswa hanya menunggu informasi yang disampaikan. Kondisi seperti ini dapat mengakibatkan suasana belajar menjadi kurang interaktif dan menimbulkan sifat pasif pada siswa.

Rendahnya kemampuan siswa dalam mata pelajaran Fisika terjadi di SMP Negeri 3
Balige. Konsep-konsep Fisika yang disampaikan masih kurang dipahami siswa, hal ini terlihat dari ulangan harian siswa pokok bahasan listrik dinamis yang memperoleh nilai rata-rata 62,25 pada tahun pelajaran 2011/2012. Dari nilai ulangan harian ini hanya 6 dari 24 orang siswa yang tuntas, yakni mencapai nilai $\geq 75$ secara klasikal. Berkaitan dengan hal tersebut, maka perlu dirancang pembelajaran yang dapat meningkatkan keterlibatan siswa dalam proses pembelajaran, sehingga mampu menumbuhkan dan mengembangkan kemampuan keterampilan kritis dan keterampilan proses sains.

Permasalahan lain dalam proses pembelajaran Fisika saat ini adalah kurangnya usaha pengembangan berpikir yang menuntun siswa untuk memecahkan suatu permasalahan. Proses ini lebih banyak mendorong siswa agar dapat menguasai materi pelajaran supaya dapat menjawab semua soal ujian yang diberikan. Kenyataan menunjukkan siswa kurang aktif dalam kegiatan belajar. Siswa lebih banyak mendengar dan menulis apa yang diterangkan atau ditulis oleh guru di papan tulis. Berdasarkan hasil penelitian dari pusat kurikulum (dalam Kaswan, 2004), ternyata metode ceramah dengan guru menulis di papan tulis merupakan metode yang paling sering digunakan.

Keterampilan proses sains dan kemampuan berpikir kritis siswa akan lebih berhasil jika diterapkan model pembelajaran sesuai yang dapat membuat siswa mencari, menemukan dan memahami Fisika itu sendiri sehingga siswa dapat membangun konsep-konsep Fisika atas dasar nalarnya sendiri yang kemudian dikembangkan atau mungkin diperbaiki oleh guru yang mengajar. Salah satu model yang cocok untuk pembelajaran yang bertujuan agar siswa dapat meningkatkan keterampilan proses sains dan kemampuan berpikir kritis adalah model Inquiry 
salah satunya adalah dengan menggunakan model inquiry training.

Menurut Joyce (2011) model pembelajaran inquiry training dirancang untuk membawa siswa secara langsung ke dalam proses ilmiah melalui latihan-latihan yang dapat memadatkan proses ilmiah tersebut ke dalam periode waktu yang singkat. Tujuannya adalah membantu siswa mengembangkan disiplin dan mengembangkan keterampilan intelektual yang diperlukan untuk mengajukan pertanyaan dan menemukan jawabannya berdasarkan rasa ingin tahunya.

Hasil pembelajaran utama dari inquiry training adalah proses-proses yang melibatkan aktivitas observasi, mengumpulkan dan mengolah data, mengidentifikasi dan mengontrol variabel, membuat dan menguji hipotesis, merumuskan penjelasan, dan menggambarkan kesimpulan. Hal ini sesuai dengan pencapaian indikator pada keterampilan proses sains dan kemampuan berpikir kritis.

Pengembangan model pembelajaran inquiry training yang inovatif berbasis riset diantaranya dengan mengembangkan teknologi informasi. Perkembangan teknologi informasi memungkinkan dihasilkannya multimedia interaktif dalam pembelajaran yang memudahkan dan membangkitkan motifasi belajar siswa dalam mempelajari Fisika.

Dari hasil investigasi awal sesuai latar belakang di atas, masalah-masalah yang dapat diidentifikasi adalah: (1) Keterampilan proses sains siswa masih lemah; (2) Kemampuan siswa dalam memecahkan masalah Fisika masih kurang; (3) Siswa tidak terlibat aktif dalam proses pembelajaran; (4) Salah satu materi Fisika yang sulit dipahami oleh siswa adalah materi listrik dinamis; (5) Penggunaan model pembelajaran yang digunakan kurang tepat dengan karakteristik materi pelajaran; (6) Kemampuan berpikir kritis siswa masih kurang. Masalahnya dibatasi pada: (1) Model pembelajaran yang digunakan adalah model pembelajaran inquiry training media komputer; (2) Hal yang akan diteliti mengenai keterampilan proses sains dan kemampuan berpikir kritis; (3) Materi pembalajaran yang diajarkan adalah listrik dinamis. Adapun rumusan masalah dalam penelitian ini adalah: Apakah ada pengaruh model pembelajaran inquiy training berbasis media komputer terhadap keterampilan proses sains dan kemampuan berpikir kritis siswa?

Keterampilan proses sains adalah kemampuan siswa untuk menerapkan metode ilmiah dalam memahami, mengembangkan dan menemukan ilmu pengetahuan. Keterampilan proses sains sangat penting bagi setiap siswa sebagai bekal untuk menggunakan metode ilmiah dalam mengembangkan sains serta diharapkan memperoleh pengetahuan baru atau mengembangkan pengetahuan yang telah dimiliki.

Menurut Gagne (Rustaman, 2003) pengetahuan tentang konsep-konsep dan prinsipprinsip hanya dapat diperoleh siswa bila ia memiliki kemampuan-kemampuan dasar tertentu yaitu keterampilan proses sains yang dibutuhkan untuk menggunakan dan memahami sains. Keterampilan-keterampilan proses sains itu ialah mengamati, menafsirkan, mengklasifikasikan, memprediksi, mengkomunikasikan, membuat hipotesis, merancang penyelidikan, menerapkan konsep atau prinsip, dan mengajukan pertanyaan.

Dalam menerapakan keterampilan proses sains ini diperlukan kemampuan berpikir kritis. Berpikir kritis adalah kemampuan untuk mengorganisasi, menganalisis dan mengevaluasi argumen, proses mental, strategi dan representasi seseorang yang diguanakan untuk memecahkan masalah, membuat keputusan dan mempelajari konsep baru, dan cara berpikir reflektif yang masuk akal atau berdasarkan nalar yang difokuskan untuk menentukan apa yang akan dikerjakan dan diyakini (Ennis, 1996).

Angelo (dalam Arif, 2007) mengidentifikasi 4 (empat) perilaku yang sistematis dalam berpikir kritis, yaitu keterampilan menganalisis, keterampilan mensintesis, keterampilan mengenal dan memecahkan masalah, dan keterampilan menyimpulkan.

\section{Model Pembelajaran Inquiry Training}

Model Inquiry Training dirancang untuk membawa siswa secara langsung kedalam proses ilmiah melalui latihan-latihan yang dapat 
memadatkan proses ilmiah tersebut kedalam periode waktu yang singkat. Schlenker (dalam Joyce, 2001) mengatakan bahwa latihan penelitian akan meningkatkan pemahaman ilmu pengetahuan, produktivitas dalam berpikir kreatif, dan keterampilan-keterampilan dalam memperoleh dan menganalisis informasi.

Model yang dipakai dalam penelitian ini adalah model latihan penelitian (inquiry training) yang bertolak dari kepercayaan bahwa perkembangan anak yang mandiri, menurut model yang akan memberi kemudahan pada siswa untuk melibatkan diri dalam penelitian ilmiah. Harapan dari model latihan penelitian ini agar siswa dapat mempertanyakan, mengapa sesuatu peristiwa terjadi, dan menelitinya dengan cara mengumpulkan data dan mengolah data secara logis.

Tabel 1. Sintaks Inquiry Model Latihan Penelitian

\begin{tabular}{ll}
\hline Fase & Kegiatan \\
\hline Pertama & Menghadapkan pada masalah: \\
& 1. Menjelaskan prosedur-prosedur penelitian \\
& 2. Menjelaskan perbedaan-perbedaan \\
Kedua & Pengumpulan data-Verifikasi: \\
& 1. Memverifikasi hakikat objek dan kondisinya \\
& 2. Memverifikasi peristiwa dari keadaan permasalahan \\
Ketiga & Pengumpilan data-Eksperimentasi: \\
& 1. Memisahkan variabel yang relevan \\
& 2. Menghipotesiskan (serta menguji) hubungan kausal \\
Keempat & Mengolah, memformulasi suatu penjelasan: \\
& Memformulasikan aturan dan penjelasan \\
Kelima & Analis proses ilmiah: \\
& Menganalis strategi penelitian dan mengembangkan yang paling efektif \\
\hline
\end{tabular}

Fase pertama mengharuskan guru untuk menyajikan situasi permasalahan dan menjelaskan prosedur-posedur penelitian pada siswa. Untuk mendapatkan peristiwa yang unik, guru harus mengerti sifat atau ciri-cirinya. Sifat umum suatu peristiwa unik yang dapat dijadikan sumber masalah adalah bahwa peristiwa tersebut harus bertentangan dengan perasaan/gagasan/ pengertian/pengalaman kebanyakan siswa tetang suatu realitas. Fase kedua, verifikasi merupakan proses dimana siswa mengumpulkan informasi tentang suatu peristiwa yang mereka alami.

Fase ketiga eksperimentasi, siswa memperkenalkan elemen-elemen baru ke dalam situasi permasalahan untuk mengetahui mungkinkah terjadi hal lain ketika data eksperimen mereka diujicoba dengan cara yang berbeda. Walaupun verifikasi dan eksperimentasi digambarkan sebagai tahap yang terpisahkan dalam model ini, pemikiran siswa dan jenisjenis pertanyaan yang mereka utarakan biasanya bergantian dan bergiliran antara dua tahap pengumpulan data tersebut.

Fase ke-empat, guru meminta siswa mengolah data dan merumuskan suatu penjelasan. Beberapa siswa memiliki kesulitan dalam membuat "lompatan intelektual" antara memahami informasi yang telah mereka kumpulkan dengan membangun penjelasan yang jelas mengenai informasi itu. Mereka mungkin memberikan penjelasan yang tidak sesuai, meninggalkan rincian-rincian yang sebenarnya esensial. Terkadang beberapa teori atau penjelasan bisa didasarkan paa data yang sama. Dalam beberapa kasus, kondisi ini sering kali berguna untuk meminta siswa mengutarakan penjelasan mereka sehingga jangkauan hipotesishipotesis yang mungkin ada bisa menjadi lebih jelas. Begitu pila dengan mengelompokkan teori-teori tersebut, siswa dapat lebih mudah memberikan penjelasan yang seluruhnya bisa merespon situasi permaslahan. 
Fase kelima, siswa diminta untuk menganalisis pola penelitian mereka. Mereka mungkin menentukan pertanyaan-pertanyaan yang sangat efektif, cara-cara bertanya yang produktif dan tidak, jenis informasi yang mereka butuhkan dan tidak mereka peroleh. Tahap ini penting seandainya kita ingin membuat proses penelitian sebagai suatu kesadaran dan mulai mencoba untuk mengembangkannya secara sistematis.

Model inquiry training ini, selain dapat mencapai tujuan sebuah pokok bahasan juga dapat meningkatkan: (1) Keterampilan proses (mengamati, mengumpulkan dan mengolah data); (2) Pelajar aktif dan mandiri; (3) Pengungkapan verbal; (4) Toleransi terhadap keadaan yang ambigu (memiliki dua arti) dan juga ketekunan; (5) Berfikir logis; (6) Sikap bahwa semua pengetahuan itu sifatnya sementara.

\section{Media Interaktif Berbasis Komputer}

Media interaktif berbasis komputer merupakan media pembelajaran mandiri yang dapat dimanfaatkan siswa dengan panduan komputer. Guru sebagai fasilitator merancang kegiatan pembelajaran sehingga siswa dapat melakukan sendiri pembelajaran baik di sekolah maupun di rumah. "Computer-based interactive media creates a multimedia learning environment that capitalizes on the features of both video and computer assisted instruction" (Molenda, 2005). Media interaktif berbasis komputer adalah sofware pembelajaran yang dapat dimanfaatkan oleh siswa secara mandiri tanpa bantuan guru. Media interaktif berbasis komputer harus dapat memadukan explicit knowledge dan tacit knowledge, mengandung fitur assemen untuk latihan, ujian dan simulasi.

\section{METODE PENELITIAN}

Penelitian ini dilaksanakan di SMP Negeri 3 Balige, Kabupaten Toba Samosir. Waktu penelitian ini dilakukan semester I Tahun Pelajaran 2012/2013. Populasi dalam penelitian ini adalah seluruh siswa kelas IX semester I di SMP Negeri 3 Balige yang terdiri dari 4 kelas berjumlah 121 orang. Pengambilan sampel dilakukan dengan cara cluster random sampling dimana setiap kelas memiliki kesempatan yang sama untuk menjadi sampel penelitian. Sampel terdiri dari kelas eksperimen dengan menggunakan model pembelajaran Inquiry Training berbasis media komputer dan kelas kontrol dengan menggunakan model pembelajaran Inquiry Training. Desain penelitian ini berupa Two Group Pretes-Postes Design. Tabel 2. Desain Penelitian

\begin{tabular}{lccc}
\hline \multicolumn{1}{c}{ Sampel } & Pretes & Perlakuan & Postes \\
\hline Kelas Eksperimen & $\mathrm{T}_{1}$ & $\mathrm{X}$ & $\mathrm{T}_{2}$ \\
Kelas Kontrol & $\mathrm{T}_{1}$ & $\mathrm{Y}$ & $\mathrm{T}_{2}$ \\
\hline
\end{tabular}

Keterangan: $\mathrm{T}_{1}$ : Pre test; $\mathrm{T}_{2}$ : Post test; $\mathrm{X}$ : Perlakuan untuk model pembelajaran Inquiry Training berbasis media komputer; Y: Perlakuan untuk model pembelajaran Inquiry Training.

\section{HASIL PENELITIAN DAN PEMBAHASAN Profil Keterampilan Proses Sains Siswa pada kelas Kontrol}

Profil keterampilan proses sains siswa pada kelas kontrol dilihat dari hasil skor pretes dan postes yang dibandingkan dengan melihat $\mathrm{N}$-gainnya agar terlihat bagaimana perbandingan peningkatan keterampilan proses sains pada kelompok kontrol setelah pembelajaran. Untuk mengetahui gambaran profil keterampilan proses sains siswa dapat dilihat dari Tabel 3.

Tabel 3. Hasil pretes, postes, dan N-gain keterampilan proses sains kelas kontrol

\begin{tabular}{clcccc}
\hline $\begin{array}{c}\text { No } \\
\text { Soal }\end{array}$ & $\begin{array}{c}\text { Aspek Keteram } \\
\text { pilan Proses Sains }\end{array}$ & $\begin{array}{c}\text { Pre } \\
\text { tes }\end{array}$ & $\begin{array}{c}\text { Pos } \\
\text { tes }\end{array}$ & $\begin{array}{c}\text { N- } \\
\text { gain }\end{array}$ & $\begin{array}{c}\text { Kate- } \\
\text { gori }\end{array}$ \\
\hline 1 & Merancang penyelidikan & 1,00 & 2,82 & 0,60 & sedang \\
2 & Menafsirkan & 1,20 & 4,40 & 0,67 & sedang \\
3 & Memprediksi & 1,30 & 4,63 & 0,71 & tinggi \\
4 & Membuat hipotesis & 1,33 & 3,93 & 0,50 & sedang \\
5 & Mengajukan pertanyaan & 0,63 & 2,30 & 0,70 & sedang \\
6 & Mengkomunikasikan & 1,10 & 2,80 & 0,59 & sedang \\
7 & Menerapkan konsep & 1,33 & 4,10 & 0,59 & sedang \\
8 & Mengklasifikasi & 0,83 & 2,50 & 0,77 & tinggi \\
9 & Mengamati & 0,60 & 1,63 & 0,81 & tinggi \\
\hline
\end{tabular}

Berdasarkan data pada Tabel 3 dapat diamati bahwa keterampilan proses sains siswa pada tiap-tiap aspek meningkat persentasinya. Keterampilan yang terlihat peningkatannya berkategori tinggi adalah keterampilan mengamati, mengklasifikasi, dan memprediksi sedangkan keterampilan yang terlihat peningkatannya berkategori sedang adalah merancang 
penyelidikan, menafsirkan, membuat hipotesis, mengajukan pertanyaan, mengkomunikasikan, dan menerapkan konsep. Keterampilan berhipotesis memiliki $\mathrm{N}$-gain 0,50 mengalami peningkatan yang paling rendah yang dibandingkan dengan keterampilan yang lain.

\section{Profil Keterampilan Proses Sains Siswa pada kelas Eksperimen}

Profil keterampilan proses sains siswa pada kelas eksperimen dilihat dari hasil skor pretes dan postes yang dibandingkan dengan melihat $\mathrm{N}$-gainnya agar terlihat bagaimana perbandingan peningkatan keterampilan proses sains pada kelompok eksperimen setelah pembelajaran. Untuk mengetahui gambaran profil keterampilan proses sains siswa dapat dilihat dari Tabel 4.

Tabel 4. Hasil pretes, postes, dan N-gain keterampilan proses sains kelas eksperimen

\begin{tabular}{clcccc}
\hline $\begin{array}{c}\text { No } \\
\text { Soal }\end{array}$ & $\begin{array}{c}\text { Aspek Keteram } \\
\text { pilan Proses Sains }\end{array}$ & $\begin{array}{c}\text { Pre } \\
\text { tes }\end{array}$ & $\begin{array}{c}\text { Pos } \\
\text { tes }\end{array}$ & $\begin{array}{c}\text { N- } \\
\text { gain }\end{array}$ & $\begin{array}{c}\text { Kate- } \\
\text { gori }\end{array}$ \\
\hline 1 & Merancang penyelidikan & 1,30 & 3,27 & 0,73 & Tinggi \\
2 & Menafsirkan & 1,07 & 5,27 & 0,85 & Tinggi \\
3 & Memprediksi & 1,33 & 5,10 & 0,81 & Tinggi \\
4 & Membuat hipotesis & 1,37 & 5,50 & 0,89 & Tinggi \\
5 & Mengajukan pertanyaan & 1,67 & 2,70 & 0,87 & Tinggi \\
6 & Mengkomunikasikan & 1,07 & 3,33 & 0.77 & Tinggi \\
7 & Menerapkan konsep & 1,23 & 5,20 & 0,83 & Tinggi \\
8 & Mengklasifikasi & 1,87 & 2,80 & 0,91 & Tinggi \\
9 & Mengamati & 0,52 & 1,80 & 0,86 & Tinggi \\
\hline
\end{tabular}

Berdasarkan data pada Tabel 4 dapat diamati bahwa keterampilan proses sains siswa pada tiap-tiap aspek meningkat persentasinya dan semua aspek terlihat peningkatannya berkategori tinggi yaitu memiliki N-gain antara 0,73 sampai 0,91 . Hal ini menyatakan bahwa model pemebelajaran inquiry training berbasis media komputer dapat meningkatkan keterampilan proses sains siswa.

\section{Profil Kemampuan Berpikir Kritis Siswa pada kelas Kontrol}

Profil kemampuan berpikir kritis siswa pada kelas kontrol dilihat dari hasil skor pretes dan postes yang dibandingkan dengan melihat $\mathrm{N}$-gainnya agar terlihat bagaimana perbandingan peningkatan kemampuan berpikir kritis pada kelompok kontrol setelah pembelajaran.
Untuk mengetahui gambaran profil keterampilan proses sains siswa dapat dilihat dari Tabel 5.

Tabel 5. Hasil Pretes, Postes, dan N-gain

Kemampuan Berpikir Kritis Kelas Kontrol

\begin{tabular}{clcccc}
\hline $\begin{array}{c}\text { No } \\
\text { Soal }\end{array}$ & $\begin{array}{c}\text { Aspek Kemam } \\
\text { puan Berpikir Kritis }\end{array}$ & $\begin{array}{c}\text { Pre } \\
\text { tes }\end{array}$ & $\begin{array}{c}\text { Pos } \\
\text { tes }\end{array}$ & $\begin{array}{c}\text { N- } \\
\text { Gain }\end{array}$ & $\begin{array}{c}\text { Kate- } \\
\text { gori }\end{array}$ \\
\hline 1 & Menganalisis & 1,20 & 3,03 & 0,65 & sedang \\
2 & Mensintesis & 5,40 & 14,87 & 0,65 & sedang \\
3 & Memecahkanmasalah & 1,37 & 3,27 & 0,72 & tinggi \\
4 & Membuat Simpulan & 5,37 & 9,33 & 0,68 & sedang \\
\hline
\end{tabular}

Berdasarkan data pada Tabel 5 dapat diamati bahwa kemampuan berpikir kritis siswa pada tiap-tiap aspek meningkat persentasinya. Keterampilan yang terlihat peningkatannya berkategori tinggi adalah keterampilan memecahkan masalah. Hal ini dikarenakan siswa dalam pembelajaran inquiry training sebagai pelaku utama dalam pembelajaran dan harus mengumpulkan data sebagai alat untuk dapat memecahkan masalah yang diajukan.

\section{Profil Kemampuan Berpikir Kritis Siswa} pada kelas Eksperimen

Profil kemampuan berpikir kritis siswa pada kelas eksperimen dilihat dari hasil skor pretes dan postes yang dibandingkan dengan melihat $\mathrm{N}$-gainnya agar terlihat bagaimana perbandingan peningkatan keterampilan proses sains pada kelompok eksperimen setelah pembelajaran. Untuk mengetahui gambaran profil kemampuan berpikir kritis siswa dapat dilihat dari Tabel 6.

Tabel 6. Hasil Pretes, Postes, dan N-Gain Kemampuan Berpikir Kritis Kelas Eksperimen

\begin{tabular}{clcccc}
\hline $\begin{array}{c}\text { No } \\
\text { Soal }\end{array}$ & $\begin{array}{c}\text { Aspek Kemam } \\
\text { puan Berpikir Kritis }\end{array}$ & $\begin{array}{c}\text { Pre } \\
\text { tes }\end{array}$ & $\begin{array}{c}\text { Pos } \\
\text { tes }\end{array}$ & $\begin{array}{c}\text { N- } \\
\text { gain }\end{array}$ & $\begin{array}{c}\text { Kate- } \\
\text { gori }\end{array}$ \\
\hline 1 & Menganalisis & 1,13 & 3,53 & 0,84 & Tinggi \\
2 & Mensintesis & 5,37 & 15,73 & 0,71 & Tinggi \\
3 & Memecahkan masalah & 1,40 & 3,60 & 0,85 & Tinggi \\
4 & Membuat simpulan & 5,37 & 10,13 & 0,78 & Tinggi \\
\hline
\end{tabular}

Berdasarkan data pada Tabel 6 dapat diamati bahwa kemampuan berpikir kritis siswa pada tiap-tiap aspek meningkat persentasinya dan semua aspek terlihat peningkatannya berkategori tinggi. Hal ini menyatakan bahwa model pemebelajaran inquiry training berbasis media komputer dapat meningkatkan kemampuan berpikir kritis siswa. 
Perbandingan Peningkatan Keterampilan Proses Sains dan Kemampuan Berpikir Kritis pada Kelas Eksperimen dan Kelas Kontrol secara Keseluruhan
Secara umum perbedaan rata-rata skor keterampilan proses sains yang diperoleh kelas eksperimen dan kelas kontrol dapat dilihat pada Tabel 7.

Tabel 7. Rekapitulasi Skor Tes Keterampilan Proses Sains

\begin{tabular}{|c|c|c|c|c|c|c|}
\hline \multirow{2}{*}{ Kelas } & \multicolumn{2}{|l|}{ Pretes } & \multicolumn{2}{|l|}{ Postes } & \multirow{2}{*}{$\mathrm{G}$} & \multirow{2}{*}{$\begin{array}{c}\text { Kategori } \\
\text { peningkatan }\end{array}$} \\
\hline & Rata-rata skor & $\%$ & Rata-rata skor & $\%$ & & \\
\hline Kontrol & 9,33 & 23,33 & 30,10 & 75,25 & 0,68 & Sedang \\
\hline Eksperimen & 9,47 & 23,67 & 34,97 & 87,42 & 0,84 & Tinggi \\
\hline
\end{tabular}

Berdasarkan Tabel 7 tampak bahwa Keterampilan Proses Sains untuk kelas eksperimen dan kelas kontrol mengalami peningkatan, akan tetapi besar peningkatannya berbeda. Pada tabel tersebut terlihat jelas bahwa terdapat perbedaan peningkatan Keterampilan Proses Sains antara kelas eksperimen dan kelas kontrol, kelas eksperimen mengalami peningkatan yang lebih besar daripada kelas kontrol.

Tabel 8. Rekapitulasi Skor Tes Kemampuan Berpikir Kritis

\begin{tabular}{|c|c|c|c|c|c|c|}
\hline \multirow{2}{*}{ Kelas } & \multicolumn{2}{|l|}{ Pretes } & \multicolumn{2}{|c|}{ Postes } & \multirow{2}{*}{ G } & \multirow{2}{*}{$\begin{array}{c}\text { Kategori } \\
\text { peningkatan }\end{array}$} \\
\hline & Rata-rata skor & $\%$ & Rata-rata skor & $\%$ & & \\
\hline Kontrol & 11,53 & 28,83 & 30,50 & 76,25 & 0,67 & Sedang \\
\hline Eksperimen & 11,57 & 28,92 & 33,00 & 82,5 & 0,75 & Tinggi \\
\hline
\end{tabular}

Berdasarkan Tabel 8 tampak bahwa kemampuan berpikir kritis untuk kelas eksperimen dan kelas kontrol mengalami peningkatan, akan tetapi besar peningkatannya berbeda. Pada tabel tersebut terlihat jelas bahwa kelas eksperimen mengalami peningkatan yang lebih besar.

Selanjutnya untuk mengetahui apakah perbedaan tersebut signifikan atau tidak, maka dilakukan uji signifikansi perbedaan rata-rata (uji hipotesis). Analisis dilakukan dengan menguji normalitas, homogenitas terhadap distribusi N-Gain kemampuan berpikir kritis kedua kelas kemudian dilanjutkan dengan uji signifikansi perbedaaan rata-rata. Hasil uji normalitas dan homogenitas pada taraf kepercayaan $95 \%$ (signifikansi $\alpha=0,05$ ) terhadap distribusi $\mathrm{N}$-gain kedua kelas.

Nilai sign Kolmogorov-Smirnov test data $\mathrm{N}$-gain keterampilan proses sains kelas kontrol 0,20 dan kelas eksperimen 0,20. Dari hasil tersebut semua nilai sig $>0,05$, artinya data $\mathrm{N}$ gain keterampilan proses sains baik kelas kontrol maupun kelas eksperimen berasal dari populasi yang berdistribusi normal. Sedangkan nilai sign Kolmogorov-Smirnov test data $\mathrm{N}$ gain kemampuan berpikir kritis pada kelas kontrol 0,08 dan kelas eksperimen 0,20. Dari hasil tersebut semua nilai sig $>0,05$, artinya data $\mathrm{N}$-gain kemampuan berpikir kritis baik kelas kontrol maupun kelas eksperimen berasal dari populasi yang berdistribusi normal.

Setelah melakukan uji normalitas, dilanjutkan dengan uji homogenitas varians yang bertujuan untuk menguji variansi populasi skor kelas eksperimen dan kontrol apakah homogen atau tidak. Untuk uji homogenitas digunakan uji Lenene statistic. Nilai sig yang diperoleh untuk data $\mathrm{N}$-gain keterampilan proses sains kelas kontrol dan kelas eksperimen adalah $0,74>0,05$. Sedangkan nilai sig yang diperoleh untuk data $\mathrm{N}$-gain kemampuan berpikir kritis pada kelas kontrol dan kelas eksperimen adalah 0,95>0,05, artinya variansi populasi skor kelas ekperimen dan kontrol data $\mathrm{N}$-gain keterampilan proses sains dan $\mathrm{N}$-gain kemampuan berpikir kritis adalah homogen.

\section{Pembahasan}

Pengolahan data N-gain keterampilan proses sains kelas eksperimen dan kontrol 
menggunakan SPSS 17. Dari pengolahan data yang dilakukan nilai probabilitas uji dua sisi adalah 0,74 > 0,05 maka Ho ditolak. Artinya peningkatan keterampilan proses sains siswa yang diterapkan model pembelajaran inquiry training berbasis media komputer lebih baik daripada keterampilan proses sains siswa yang diterapkan model pembelajaran inquiry training pada materi pembelajaran listrik dinamis.

Pengolahan data $\mathrm{N}$-gain kemampuan berpikir kritis kelas eksperimen dan kontrol menggunakan SPSS 17. Dari pengolahan data yang dilakukan nilai probabilitas uji dua sisi adalah 0,95 > 0,05 maka Ho ditolak. Artinya peningkatan keterampilan proses sains siswa yang diterapkan model pembelajaran inquiry training berbasis media komputer lebih baik daripada kemampuan berpikir kritis siswa yang diterapkan model pembelajaran inquiry training pada materi pembelajaran listrik dinamis. Penemuan dalam penelitian ini menunjukkan bahwa model pembelajaran inquiry training berbasis media komputer dapat meningkatkan keterampilan proses sains dan kemampuan berpikir kritis siswa. Hasil penelitian ini hampir sama dengan penelitian Damanik (2013) bahwa model pembelajaran inquiry training dapat meningkatkan kemampuan berpikir kritis dan sikap ilmiah siswa, hampir sama juga dengan hasil penelitian Hayati (2013) bahwa model pembelajaran inquiry training berbasis multimedia dapat meningkatkan hasil belajar Fisika siswa.

\section{SIMPULAN}

Berdasarkan hasil penelitian, pengolahan dan pembahasan yang telah dilakukan, maka dapat disimpulkan sebagai berikut: (1) Model pembelajaran Inquiry training berbasis media komputer yang diterapkan pada kelas eksperimen secara signifikan dapat lebih meningkatkan keterampilan proses sains siswa dibandingkan dengan model pembelajaran inquiry training yang diterapkan pada kelas kontrol, hal ini dapat dilihat pada nilai Ngain kelas eksperimen 0,75 (kategori tinggi) lebih besar daripada $\mathrm{N}$-gain kelas kontrol 0,67 (kategori sedang). (2) Model pembelajaran Inquiry training berbasis media komputer yang diterapkan pada kelas eksperimen secara signifikan dapat lebih meningkatkan kemampuan berpikir kritis siswa dibandingkan dengan model pembelajaran inquiry training yang diterapkan pada kelas kontrol, hal ini dapat dilihat pada nilai Ngain kelas eksperimen 0,84 (kategori tinggi) lebih besar daripada Ngain kelas kontrol 0,68 (kategori sedang).

\section{DAFTAR PUSTAKA}

Arif, A. 2007. Memahami Berpikir Kritis. http://researchangius.net/1007arief3.httm. [4 Mei 2012]

Damanik, D.P. 2013. Analisis Kemampuan Berpikir Kritis dan Sikap Ilmiah pada Pembelajaran Fisika Menggunakan Model Pebelajaran Inquiry Training (IT) dan Direct Instruction (DI). Medan: Tesis UNIMED.

Ennis. 1996. Critical Thinking. New Jersey: Prentice Hall, Uper Saddle river.

Hayati. 2013. Efek Model Pembelajaran Inquiry Training Berbasis Multimedia dan Motivasi Terhadap Hasil Belajar Fisika Siswa. Medan: Tesis UNIMED.

Joyce, B. 2011. Models of Teaching. Yogyakarta: Pustaka Pelajar.

Kaswan. 2004. Peningkatan Pemahaman Konsep dan Kemampuan Berpikir Kritis Siswa Melalui Kegiatan Laboratorium Berbasis Inkuiri Pada Pokok Bahasan Rangkaian Listrik Arus Searah. Bandung: Tesis Pada SPs UPI Tidak Diterbitkan.

Molenda, M., Smaldino, Sharon. 2005. Intructional Technology and Media of Learning. New Jersey: Pearson Merrill Prentice Hall.

Rustaman, N. 2003. Media Pembelajaran. Jakarta: Depdiknas Dirjen Dikdasmen Direktorat Pendidikan Lanjutan Pertama.

Wartono. 2003. Strategi Belajar Mengajar Fisika. Malang: Jurusan Fisika FPMIPA UNM. 